\title{
Berkshire GDP passionate about dentistry
}

\author{
Dipesh Kothari was the second-ever recipient of the British Dental Association's \\ Joy Harrild Award for Young Dentists (BDA) in 2018. He lives in Reading and has \\ recently become a parent.
}

\section{Since graduating from Glasgow University Dipesh has completed an MSc in Implantology and training in restorative dentistry. He is a member of the BDA GDP committee and his local BDA Reading Section committee, of which he is a past Chair, and is a member of the ITI UK \& Ireland communications working group. Last year he became an ambassador of the Young ITI, a group creating educational events in implant dentistry.}

Dipesh has teaching roles as an Honorary Lecturer at the University of Bristol and on a one-year dental implant course in London.

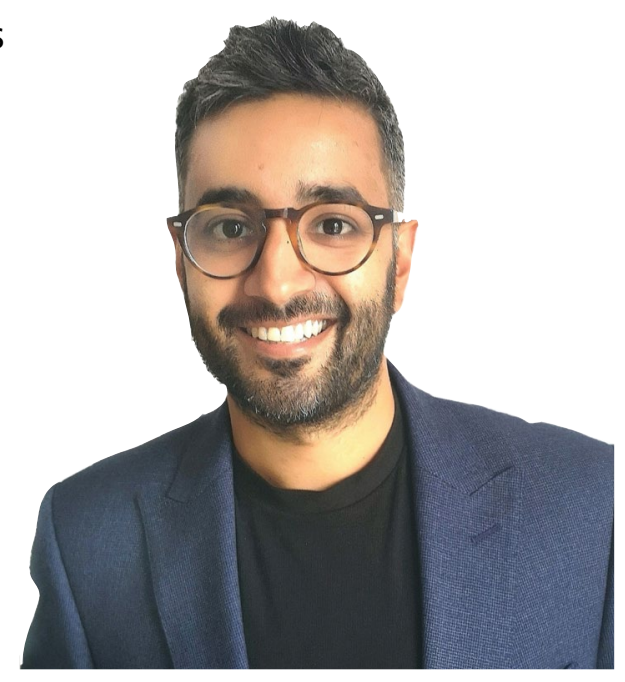

\section{What attracted you to dentistry originally?}

Working with people has always been something I have enjoyed. Dentistry allowed me to combine this with my interests in science. I have family members who are dentists and watched their enjoyment of the role. Work-life balance was another big draw.

I graduated from Glasgow in 2009. I really enjoyed Glasgow both as a city and as a university. The teaching staff were all great and invested in our development. I really enjoyed getting away from London, where I am from originally, and Scotland is still a place I travel back to every year both to travel and visit friends.

\section{Where do you work at the moment?}

I now work at four practices: three across Berkshire and one in St Albans. I work as a GDP in one site and as a visiting implant dentist at three sites. I really enjoy the variety this provides.

Previously, my experience has included a year as a Maxfac SHO in Newcastle, a stint in Australia in the middle of a year's world tour, and various GDP roles in the UK.

\section{Which are your main areas of interest within dentistry?} Implant dentistry and restorative dentistry. I have an additional interest in dental photography. I have lectured at multiple hands-on study clubs on this topic.

Do you plan to specialise further in the future?

Whilst I don't plan to formally specialise in the future, I have identified courses to further my education in advanced restorative dentistry and implant dentistry. Some of these courses are outside of the UK, which will be a new experience for me.

\section{How has the pandemic affected you?}

The last ten months have been a challenge as they have for most. During the periods I was unable to work I used the time to set up a podcast and Facebook group on implant dentistry called 'Short Talks'. This proved to be a great use of my time as not only did I learn from others but it grew my dental network outside of my bubble.

There were many skills I picked up that I am certain will be useful in the future.

I live with my wife who has been working from home throughout this period in her role as an HR manager.

I have also been able to explore the Thames Valley region further.

Why do you think you were nominated for the Joy Harrild Award for Young Dentists?

I think I was nominated as I enjoy taking part in dentistry in various roles outside of the clinical environment, including positions to help other dentists, and for my interest in continual education.

It is the variety of roles that keep dentistry interesting for me. I enjoy working with people and committees are a great way to work with likeminded people. I've met some good friends from these roles.

\section{How did it feel to win?}

Winning this award felt like a huge honour and was a proud moment for me. To be selected by my peers within the profession is a great feeling.

It is a moment where I could step back and reflect. As these were all things I had enjoyed doing I hadn't thought of them as a body of work.

\section{How was the awards ceremony?}

It was a really nice evening honouring a wide range of dentists, all of whom had made long-term contributions to the dental community in so many different ways. It was great to see these individuals be noticed and celebrated. Personally, it was great to have people come up and say encouraging words and give advice to me over the evening. 
\$4 What are you most looking forward to post-pandemic? Meeting my family, friends, and exploring more of the UK again. The pandemic has been great at showing me that the simple things are the most important. I'm sure this is the case for many.

\section{Any future plans you'd like to share, career or otherwise?}

I've never been one for long-term goals. I'm a big believer in taking opportunities that present themselves and seeing where they take you. I know that I enjoy working with people and sharing skills. Hopefully more teaching and working with people is in my future.

\section{Would you encourage others to nominate a young dentist for the} Joy Harrild award?

I would strongly recommend this. Even being put forward as a nomination is such a big vote of confidence in someone. There are young dentists working to help improve things for those around them all across the UK. It is great that there is an award to recognise contribution to the profession outside of clinical dentistry.

The BDA's Joy Harrild Award for Young Dentists is open for nominations for dentists who are within ten years of qualifying who have made a significant contribution to the profession. Nominations for the next round close on 30 April 2021. For more information and to nominate, visit https://www.bda.org/about-the-bda/honours-and-awards/ joy-harrild-award-for-young-dentists.

\section{Two-thirds of children did not see an NHS dentist last year}

NHS dental attendance figures published in February show that over two-thirds of children (70.2\%) in England did not see an NHS dentist in the 12 months to 31 December $2020 .^{1}$

In 2019, over six in ten children under 16 saw a dentist; in 2020 , it was less than three in ten.

Mr Matthew Garrett, Dean of the Faculty of Dental Surgery at the Royal College of Surgeons of England, said: 'While it is not surprising the number of children who saw an NHS dentist dropped so dramatically in 2020, we must improve access this year to avoid long-term damage to children's teeth'

\section{Reference}

1. NHS Digital. NHS Dental Statistics for England 2020-2021, Biannual Report. 25 February 2021. Available at: https://digital.nhs.uk/data-and-information/ publications/statistical/nhs-dental-statistics/2020-21-biannual-report (accessed 1 March 2021).

\section{Professor John Harold Jones}

We are sad to announce the recent death of Professor John Harold Jones. Professor Jones was British Dental Association (BDA) President in 1994. An obituary will follow. 